\title{
Guided Reading Approach to Reach Students' Reading Comprehension: A Descriptive Qualitative Research
}

\author{
Wira Hayu Wulan Sya'ban', Reflinda ${ }^{2}$ \\ ${ }^{2}$ Faculty of Tarbiyah and Teaching Training ${ }^{1}$, State Islamic Institute of Bukittinggi Bukittinggi, \\ Indonesia \\ *wirahayuwsya931@gmail.com
}

\begin{abstract}
This research was aimed to find and look on how Guided Reading Approach can reach students' reading comprehension. The researcher found that there were some weaknesses of Guided Reading Approach. They were: students sometimes did not do the real discussion; they tended to converse to other students, the discussion tended to be under the influence of some prominent students, Guided Reading Approach need extra time to be applying within the class, and it is difficult to do monitoring and coaching for each students. Therefore, the researcher analyzed how important do guided reading approach's steps contribute to reach students' reading comprehension. The design of the research was descriptive qualitative research. The data were collected by doing analyzing and exploring some journals, books, both printed and electronic documents, and other sources or information that relate to the research. The researcher found that some steps of guided reading approach contributed much to reach students' reading comprehension even though the other steps contain weakness. However, those other steps played as a bridge to continue to the next step in guided reading approach to reach the indicator of reading comprehension. The steps contributed much to reach students' reading comprehension were: picture walk, predicting, discussing vocabulary, discussion text features, activating background knowledge, monitoring, asking questions and listening to the students' read, feedback, strategies, assessment and discussion.
\end{abstract}

Keyword: Guided Reading Approach; Reading Comprehension

\section{Introduction}

There are four skills that must be learnt by the students in learning English. They are listening, speaking, reading, and writing. Reading is one of skills that is crucial to be taught to the students. It is an activity which correlates the students with the written text to get the meaning. Reading is a fluent process of readers combining information from a text and their own background knowledge to build meaning [1]. It is a complex process because during reading students not only have to read a text or passage, but they also need to associate the material that they read with their background knowledge to understand that text or passage

Understanding the text by success in constructing meaning from written text with students' background knowledge is the goal of reading. It is called reading comprehension. Reading comprehension as the ability to take information and derive sentence and discourse interpretation [2]. It is the process through which the recognized words are transformed into a 
meaningful idea. It means that reading comprehension asks students to have the ability to make a conclusion by their own interpretation based on the text or passage that they have read.

In order to improve students' reading comprehension, there are some approaches, methods, strategies, or techniques that can be used by the teacher. One of approach that can be used by the teacher to teach reading is Guided Reading. Guided reading is an approach developed by Fountas and Pinnell in 1996 to teach reading for the students' in a small group setting [3]. It focuses on students coaching in reading process. In guided reading, the students are directed to understand the meaning of text that they read depend on the students need. Teacher put the students in some groups based on their reading achievement, and the teacher afterward will support students to help them in understanding the text or passage based on the students need in the groups. Moreover, the purpose of guided reading is that teacher will help the students learn how to use independent reading strategy. The students are also helped to learn effective strategies for processing text with understanding

Guided reading involves students' reading practice strategies; it also encourages students in increasing their comprehension, accuracy, fluency, vocabulary, and reading level [4]. However, there are weaknesses of guided reading approach implementation. In implementing guided reading approach, students still converse to the others during the discussion. They did not enthusiastic to utter their prediction and discussion [5]. Guided reading approach is in discussion setting. Some disadvantages of discussion setting. It is difficult to predict about what will happen along reading process within the group, a discussion may under control of more prominent students, discussion will take much time, discussion problem sometimes can be out of the topic so that it is difficult to limit its problem, and during discussion, some students may have lack confidents to utter their opinion [6]. Therefore, it can be assumed that guided reading needs extra time to be implemented inside the class since learning process will also needs extra time to finish the steps. Besides, the researcher also assumed that it is impossible to collect reading problems from each students since it also need extra time especially for coaching.

Related to the explanation above, the researcher is interested to look how guided reading approach affects and improve students' reading comprehension while it has said that it has certain weaknesses in setting. Therefore, the researcher will conduct a research under the title: "Guided Reading Approach to Reach Students' Reading Comprehension."

The researcher formulates the question of the research is "How is Guided Reading Approach to Reach Students' Reading Comprehension?"

\section{Review of Literature}

A. Reading Comprehension

Reading is a process in which readers try to draw inference from the written text of passage to their own inference to get comprehension. While comprehension is the ability to understand words, ideas and relationship between ideas within a text [2]. Hence, reading comprehension is constructing the meaning of written text by making inference into meaningful idea.

B. Reading Comprehension Assessment

To assess reading comprehension, some criteria needed are comprehending lexical writing items and being able to derive the meaning of unfamiliar items, understanding sentences in the text, understanding writer's idea and purpose within the text, drawing the inference of the text, and understanding the tone and style of text [7].

C. Guided Reading Approach 
Guided reading is an instructional context for supporting each reader's development of effective strategies for processing novel texts at increasingly challenging levels of difficulty [8]. It is also an approach which is used to teach reading in a small group setting with doing coaching for students [3]. Thus, guided reading approach is not only provided the teacher to do monitoring, and coaching to help students and support them to comprehend the written text, but also support the students to build reading power.

\section{Methodology}

The setting of this research was descriptive qualitative research because the researcher wanted to find out and describe how guided reading approach can reach students' reading comprehension. Descriptive research is a research conducted to solve research problem by providing the data, analyzing the data, and making interpretation about the data [9]. While qualitative research is a research conducted to find out human's problem by providing the entire description and complex ideas by using words or linguistic or a language from the sources in research setting [10]. Hence, a descriptive qualitative research is a research that describes phenomenon, facts, or reality by using words explanation to solve research problem.

In this research, the researcher used documentation to collect the data. The documentation is a record of events that have already passed. The document can be a form of writing, drawing, or the monumental work of someone [11]. Besides, a documentation is a collection of data about such as notes, transcripts, books, newspapers, magazines, etc [12]. Therefore, techniques of the data collection that would be used in this research is the note, transcripts, books, and journals about the material related to Guided Reading Approach in order to reach Reading Comprehension.

The researcher used content analysis in order to analyze the data. Content analysis the researcher will do choosing process, comparing, combining, choosing various definitions which are relevance [12]. Meanwhile, if a researcher took documentation as a tool to collect the data, and he decided to use content analysis, first of all, he should to plan how to choose and collect the book content to be analyzed. The researcher should to make a broad the categories of what he thinks important to be identified related to the research. Next, he should compare those categories among the other sources which are identified too. It could be concluded that the researcher choose and collect the sources related to the research that would be found out [10]. The researcher might take note while finding the materials related to the focus of this research. After that, the researcher did the coding based on the notes that have been taken in the first step. It means that the researcher made an interpretation related to the notes. Finally, the researcher would take a conclusion of the association between the data and the research focus. Content analysis, on the other hand, is the way how the researcher interpret research topic, read the symbols within it, and how the researcher find connection between it.

\section{Result and Discussion}

The data was got by focusing on analyzing how far and how important the components of each step of Guided Reading Approach contribute to the goals of reading comprehension. The analyzing process will be related to the questions: What for do the sub steps are done? What 
will happen if one of sub steps is missing in guided reading procedure? Do the sub steps can reach reading comprehension's goals? Who said that the sub steps are important? and How important are those sub steps within the step?

The questions above arouse based on a theory of content analysis explained by Gunawan [10]. He says that in analyzing the content of a book, a researcher needs to plan how to choose and how to take a book content to be analyzed. A researcher needs to develop relevance categories to identify which theory those are important to his research. After that, a researcher will compare those categories among other book sources which are being found. Hence, the explanation of Gunawan above guided the researcher to formulate those questions to look and find more detail of the process of how the step of guided reading can reach students' reading information.

\section{Before Reading}

Before reading section, there are sub steps that should be done to get the purpose of reading. They are:

a. $\quad$ Grouping

Place the students within four to six based on the information of running record. Grouping is a condition in which students who sit within a small group setting which is organized for learning matter [13]. It is aimed to give teacher a way to approach reading instruction systematically so that students' needs are met [4]. The grouping activity may not contribute so much to achieve reading comprehension, but it is prerequisite to continue to the next step within guided reading. This grouping is determined based on students' running record. Hence, students will gather inside the group depend on their achievement in running record. The researcher assumes that his grouping is one of sub steps that cannot be separated from guided reading.

b. Picture walk

Picture walk is one of reading strategy that often be used by the teacher in the class [14]. It allows the students to establish interest in the story and to help them build good expectation of what will happen in the story so that reading comprehension will be got. It is because a picture can be clue for students to guess the unfamiliar word within the text and predict of story plot. Without picture walk, students may difficult to interfere of the text that they read because they certainly focus of only words within the text. Besides, if there is only a paragraph of a story, there is possibility for the students to get bored and struggle while understanding the text. The text will be given by the teacher for students for each group, and it can be infer that picture walk has self contribution to achieve reading comprehension indicators.

c. Predicting

A predicting is a reading strategy that is used to anticipate what is to come [15]. Reading involves some strategies such as guessing, predicting, checking, and asking oneself questions [16]. If a useful strategy is important to teach students to get comprehension while prediction is one of those strategies; hence, prediction is important.

In guided reading process after using picture walk, it is important to do prediction. Since at the time students are given a picture, it is impossible to interpret the use of picture without making prediction of that picture. A picture may automatically encourage students to predict what the story about. If students can build their prediction about the story written in the text, they can be expected to achieve the indicator of reading comprehension.

d. Discussing the vocabulary

Vocabulary is the basic component for mastering English skill. It will be hard to master a language without mastering certain number of vocabularies [17]. Purpose of guided reading is 
to help students to have reading power and comprehension. Those purposes cannot be got without knowing any vocabulary within text that would be read. Hence, discussing vocabulary is essential, and vocabulary cannot be neglect in learning a language.

Guided reading approach provided teacher to introduce students to learn difficult vocabulary that will make them struggle in reading process. Since teacher has already known her students' reading achievement based on running record, it will put teacher easier to predict which vocabulary that is unfamiliar for her students. Without discussing vocabulary, students may hard to get the meaning of the content within the text. It is the reason why the teacher has to discuss new vocabulary with the students.

e. Discussing text features

Before teaching strategy, it is important for the teacher to recognize what text will be given to students. Since text feature is one of factors influencing students' comprehension. A teacher must recognize factors within a text that can enhance or impair comprehension. These factors fall into three categories: text features, text organization, and text content. Text features include all the components of a story or article that are not the main body of text. These include the table of contents, index, glossary, headings, bold words, sidebars, pictures and captions, and labeled diagrams. While text organization refers to pattern and structure used by the author to write the text, and text content is what teacher want for the students to read [18]. Discussing these text features, text organization and text content is important in guided reading because students may get problem during reading if it is not discussed.

By knowing text feature, students will get description of text that will be read, and they can ask questions related to it before reading to the teacher if they do not want to get misunderstanding about text. According to English middle school syllabus, the texts usually learnt are descriptive text, announcement text, recount text, narrative text, factual report text and procedure text.

f. Activating background knowledge

Activating background knowledge is one of principle to teaching reading [1]. Activating student's background knowledge can influence reading comprehension. Background knowledge includes all of experiences that students' bring to a text. It consists of life experience, educational experience, knowledge of how a text can be organized rhetorically, knowledge of how first language work or how second language work, and also a knowledge of cultural pattern [1]. These background knowledges can enhance reading comprehension especially by setting goals, asking questions, making predictions, teaching text structure, and etc. If students find problem with the text topic, activating background knowledge may be useful. Hence, incorrect background knowledge will also influence students' comprehension about the text. This is why activating background knowledge need to be considered.

Activating background knowledge enables students to make inferences about what they are reading [19]. It also draws their attention to the essential information to the main knowledge, and it can provide a plan for recall.

\section{During Reading}

\section{a. Monitoring}

Principles underlying the development of reading comprehension are verifying prediction, monitoring comprehension, identifying author bias and intent, and having goals of reading in mind [20]. In monitoring process, students look how well they understand learning material.

Teacher will move from one students to the other students to listen to their reading and look again students' self-monitoring. There are several strategies can be used for monitoring: make connections, predictions, inferences, use context clues, use text features, identify text 
structures, use graphic organizers to pinpoint particular types of text information and write comments or questions on self-stick notes or in the margins [19].

The researcher assumes that this monitoring is the main point of guided reading approach characteristic. It is because from the definition of guided reading, teacher teaches reading in small group setting while providing individual coaching. The coaching is done by doing monitoring to look students' reading process during reading.

b. Asking question and Listening to the students' read

In guided reading, self-monitoring, asking question and listening to the students' read are united. Questioning answer is a reading comprehension strategy developed to clarify how students approach the task of reading texts and answering questions [21]. Assessing by giving questions during reading in other word will encourage teacher to do coaching to students, and encourage teacher to teach reading strategy.

This questioning section cannot be separated from guided reading approach because the main point of guided reading approach is coaching and monitoring during reading. Coaching and monitoring is done by asking students' question.

c. Feedback

In guided reading approach, a feedback is needed to make students know their ability of reading comprehension so that they can be motivated. A feedback can be information about the process of an activity in form of evaluative response [22]. Hence, while teacher do monitoring during reading in guided reading approach, asking students questions, listening to their read, it is time for teacher to give feedback for students.

A feedback can be correction of the process, and if the process is correct, it will turn to praise or compliment. It is will also determine students' achievement to get reading comprehension. Incorrect feedback can also influence students' reading achievement. Students, on the other hand, will also get incorrect understanding of text, or they may lose motivation to read text.

\section{d. Strategies}

Strategy is a tool for active, self-directed involvement that is necessary to develop students' communication ability. The strategies can be: having a purpose (gaining students to get what they want to get from text), previewing (identifying topic, main idea, and text organization), skimming (looking quickly through text to get general idea of what is about), scanning (looking quickly through the text to locate specific information, predicting, activating background knowledge, inferring, etc [15]. Those reading strategies are got to solve reading problem. Hence, without strategy reading problems may hard to be solved. Strategy is also a way to get reading purpose. This is why a teacher should teach students to transform a strategy to skill. It means that students will automatically use those strategies without think so much of using it.

A strategy is also reading principle that must be taught to students. Hence, reading cannot be separated from strategy because the way to solve reading problem is by using strategy. The researcher assumes that a strategy can be taught through coaching or by giving feedback during monitoring.

3. After Reading

a. Assessment

An assessment is the way to get to know the students and their quality [23]. An assessment can be used to assess students' reading comprehension. Teacher can measure how far students' understand the text given. One of goal of guided reading approach is reading comprehension. To get to know whether students reach that goal, it is crucial to measure it. 
Basically, the assessment has been started from the beginning of guided reading approach. The process of Assessment for learning includes classroom interaction, questioning, structured classroom activities, and feedback geared at helping students to bridge the learning gaps [24]. Students are also actively engaged in the assessment process through self- and peerassessment. Therefore, assessment can be benchmark for teacher of whole aspect of learning material.

In order to assess students' reading comprehension, it can be done by giving the questions, evaluating students through open-ended tasks such as answering essay questions, doing science experiments, projects, and presentations, and developing portfolios, student dialog, and formal standardized assessment [25]. It can be concluded that the way to assess students' reading comprehension can be various ways. It can be done by observing students during reading and monitoring in guided reading, by asking them questions, asking them to tell their comprehension, or it can be assess by using formal assessment for example by giving test form.

b. Discussion

The final step in guided reading approach is by doing discussion. The discussion is done as a whole. Teacher and students will totally discuss about the text during reading. Discussion is a condition in which teacher and students or students and students interact among each other to share the idea, opinion, and thought in learning process [26]. By doing this discussion, students can share their idea, problems, the strategies have been used to comprehend the text, etc

The reason of why discussion is important in the last reading section in guided reading is that by doing discussion, students' misunderstanding toward the text will be fixed. One student can also get the other ways to solve reading problem from another student. If there is one or some students who still do not understand text content, then teacher will review the text. Furthermore, a discussion can make students' strongly comprehend text, and it is also very useful to be used to reach guided reading goal

\section{Conclusion}

The conclusion of this research are: firstly, It can be infer that each step of guided reading approach is united to support one another. Second, several steps play the important role to affect students' reading comprehension. Third, Grouping may not contribute directly to reach students' reading comprehension, but it is prerequisite to continue to the next step in Guided Reading Approach. A grouping is also a special characteristic of Guided Reading Approach. Last, monitoring is the main point of Guided Reading Approach characteristic. Hence, at the time the teacher decide to adapt Guided Reading Approach to help students to reach their comprehension in reading, a teacher should consider students' learning condition and learning time duration.

\section{References}

[1] D. Nunan, "Practical English Language Teaching," New York: McGraw-Hill Companies.Inc., 2003 
[2] Emisari, P. Raja, and A. Nurweni, "Metacognitive Reading Strategy Training for High School Students," Journal of fkip.unila vol. 5, No. 2, 2016: U-JET: jurnal.fkip.unila.ac.id

[3] A. L. Herrell, \& M. Jordan, "Fifty Strategies for Teaching English Language Learners," New Jersey: Pearson Education, 2004

[4] S. Aessie, J. Dunn, \& N. Spencer, "A Guide to Guided Reading," An NLSD (Northern Lights School Divition) No.69, Professional Literacy Project 2014-2015

[5] N. M. Oktaviyanti, A. Muti'ah, E. S. Widayanti, "Penerapan Metode Guided Reading Untuk Meningkatkan Kemampuan Membaca Cerita Anak Siswa Kelas VII-A Smp Negeri 1 Maesan," Jurusan Pendidikan Bahasa dan Seni, Fakultas Keguruan dan Ilmu Pendidikan Universitas Jember, Artikel Imiah Mahasiswa 2015

[6] N. Ermi, "Penggunaan Metode Diskusi untuk Meningkatkan Hasil Belajar Materi Perubahan Sosial pada Siswa Kelas XII SMA Negeri 4 Pekanbaru," Jurnal SOROT, Volume 10, Nomor 2, Oktober 2015 halaman 155 - 168 Lembaga Penelitian dan Pengabdian kepada Masyarakat Universitas Riau

[7] D. P. Harris, "Testing English as A Second Language," United States of America: McGraw-Hill, Inc., 1969.

[8] I. C. Fountas \& G. S. Pinnell, "Guided Reading The Romance and The Reality," The Reading Teacher Vol. 66, Issue 4, December 2012, January 2013

[9] C. Narbuko, and A. Achmadi, "Metodologi Penelitian," PT Bumi Aksara, 2016

[10]I. Gunawan, "Metode Penelitian Kualitatif Teori dan Praktik," PT Bumi Aksara, 2015

[11]Sugiyono, "Metodologi Penelitian Kuantitatif Kualitatif dan R\&D," Alfa Beta Bandung, 2010

[12]A. Azizah, dan B. Purwoko, “ Studi Kepustakaan Mengenai Landasan Teori dan Praktik Konseling Naratif,” Jurnal BK UNESA Vol. 7, No. 2, 2017

[13]D. Kartikasari, "Peningkatan Hasil Belajar Siswa Dalam Pelajaran Bahasa Inggris Melalui Metode Kerja Kelompok di Smp Negeri 3 Palembang Wahana Didaktika," Vol. 15 No.3, September 2017 : 42-52

[14]J. Baskwill, "Book as Bridge: Permission copy for classroom use," Book pieces, 2010: Pembroke Publisher

[15]D. Nunan, “Second Language Teaching \& Learning," U.S.A: An International Thomson Publishing Company, 1999

[16]A. Solihah, \& A. Rustandi, "Improving Reading Skill of Procedure Text Through Picture Walk," Project Professional Journal of English Education, vol. 3 No. 2 March 2020: IKIP Siliwangi

[17]F. N. Hanifia, "The Use of Vocabulary Journal in Enriching Students' Vocabulary Mastery and The Students' Attitude Toward Its Use,” Journal of English Education 2013, 1(1) $81-88$

[18]M. J. Kelley, and N. C. Grace, "Guiding Students Through Expository Text With Text Feature Walks,” The Reading Teacher, 64(3), pp. 191-195. 2010 International Reading Association

[19]B. Usman, Z. A. Aziz, and N. R. Absida, "Improving Reading Compehension Using Metacognitive Strategies,” English Education Journal (EEC), 8 (4), 425-438, October 2017 
[20]S. Signgh, "Developing Reading Comprehension ThroughMetacognitive Strategy Training," Asian EFL Journal Research Articles Vol. 23 Issue No. 3.3 May 2019: KwanseiGakuin University Japan

[21]C. M. Zulya, A. Nurweni, and G. E. Putrawan, "Improving Students' Reading Comprehension through Question-Answer Relationship (QAR) Strategy. (A Journal of English Education Study Program University of Lampung" 2016/2017

[22]A. Suarman, "The Effect of Feedback on Student's Writing Accuracy," ELTIN Journal. Volume 1/I, October 2013

[23]S. Jimaa, "The Impact of Assessment on Students' Learning," SciVerseScienceDirect: Procedia - Social and Behavioral Sciences 28 (2011) 718 - 721)

[24]A. M. A. Umar, "The Impact of Assessment for Learning on Students' Achievement in English for Specific Purposes A Case Study of Pre-Medical Students at Khartoum University: Sudan," English Language Teaching; Vol. 11, No. 2; 2018: Published by Canadian Center of Science and Education

[25]J. S. Caldwell, "This is a chapter excerpt from Guilford Publications. Comprehension Assesment: A Classroom Guide Copyright" (C) 2008

[26]N. Huda, "Upaya Meningkatkan Hasil Belajar Matematika Melalui Metode Diskusi Pada Siswa Kelas VI SD Negeri 24 Indralaya," Jurnal ilmiah Bina Edukasi ISSN 1979-8598 EISSN: 2655-8378 http://journal.binadarma.ac.id/index.php/jurnalbinaedukasi Vol. 12, No. 2, Desember 2019, 42-51) 